\title{
Ethical Dilemmas on Accountants
}

\section{Dwi Marlina Wijayanti ${ }^{1}$, Frisky Jeremy Kasingku $^{2}$ and Risa Rukmana ${ }^{3}$}

\author{
Universitas Islam Negeri Sunan Kalijaga Yogyakarta, \\ Indonesia ${ }^{1}$, Universitas Klabat, Manado, Indonesia², \\ STIE Tri Dharma Nusantara, Indonesia ${ }^{3}$; \\ frisky.kasingku@gmail.com ${ }^{2}$
}

\begin{abstract}
Internal factors play an important role in decision making, especially under ethical dilemma conditions. Therefore, we examine the internal factors of individuals such as gender, age, and level of education in making decisions under ethical dilemma circumstances. This study uses a survey by Aluchna and Mikolajczyk and Eweje and Brunon to collect data. 86 undergraduate and 19 postgraduate students are the respondents for this study. Nonparametric chi-square tests are conducted to test the hypotheses. As a result, women are more ethical than men. Age does not affect the attitude when faced with ethical dilemmas. Moreover, there is no difference in perception between age and level of education toward ethical dilemmas. This study contributes for practical field. Human resource can consider which person to recruit to fit a job, and early ethical education should be done in order for the individual to reach the highest ethical stage.
\end{abstract}

Keywords: Ethical dilemma; gender; age; level of education 